\title{
A morphological comparison of the cavity dwelling honeybees of Borneo Apis koschevnikovi (Buttel- Reepen, 1906)* and Apis cerana (Fabricius, 1793)
}

\author{
T. E. Rinderer ${ }^{{ }^{* *}}$, N. Koeniger 2 , S. Tingek ${ }^{3}$, M. Mardan 4 and \\ G. Koeniger 2
}

(with the technical collaboration of L. Davis ${ }^{1}$ and J. Stelzer ${ }^{1}$ )

1 U.S. Department of Agriculture, Agricultural Research Service, Honey Bee Breeding, Genetics and Physiology Laboratory, 1157 Ben Hur Road, Baton Rouge, LA 70820, USA;

2 J.W. Goethe Universität, Institut fur Bienenkunde (Polytech. Ges.); Frankfurt am Main, Karl-vonFrisch Weg 2, D-6370 Oberursel, FRG;

${ }^{3}$ Agricultural Research Station, Penom, Sabah, Malaysia;

${ }^{4}$ Universiti Pertanian Malaysia, Department of Plant Protection, 43400 UPM, Serdang, Selangor, Malaysia

(received 9 June 1988, accepted 26 July 1989)

Summary - Complete morphological descriptions using measurements common to honeybee taxonomy are provided for Apis koschevnikovi (Buttel-Reepen 1906) and Apis cerana (Fabricius 1793) from North East Borneo. Overall, $A$. koschevnikovi is larger than the sympatric A. cerana. A. koschevnikovi has a morphology which is very different from all other well-described forms of honey bees.

\section{Apis koschevnikovi-Apis cerana - morphometrics}

\footnotetext{
* Two earlier reports on this bee, Tingek et al. (1988) and Koeniger et al. (1988), used the name $\boldsymbol{A}$. vechti (Maa, 1953). Ruttner et al. (1989) reports Buttel-Reepen first named the species in 1906 as Apis koschevnikovi. Examinations of museum specimens confirm that $A$. vechti is a later synonym for A. koschevnikovi.

** Author to whom correspondence should be addressed.
} 


\section{INTRODUCTION}

The cavity-nesting Saban honeybee, Apis koschevnikovi (Buttel-Reepen, 1906) has recently been re-evaluated and recognized as a valid biological species based on morphological evidence of a unique endophallus (Tingek et al., 1988) and behavioral evidence that $A$. koschevnikovi drones have a different mating flight time from that of sympatric $\boldsymbol{A}$. cerana drones (Koeniger et al., 1988). In addition, 2 other characters were described as species specific. First, $A$. koschevnikovi drones have a secondary sex characteristic of a hairy fringe on the margin of the tibia of the hind leg. Secondly, worker bee forewing venation shows a cubital index which is both quite large and quite varied (Tingek et al., 1988).

Recent descriptions of $A$. koschevnikovi (Tingek et al., 1988; Koeniger et al., 1988) and the description of Buttel-Reepen (1906) focus on characteristics which support the recognition of $A$. koschevnikovi as a species. In addition, some behavioral traits have been reported by Mathew \& Mathew (1988). However, all these reports are incomplete descriptions because they do not describe the morphological measures which are commonly used in modern honeybee taxonomy (Ruttner, 1988). This paper provides these morphometric details for $A$. koschevnikovi. In addition, a description is provided of $A$. cerana, the Eastern honeybee, which is sympatric with $A$. koschevnikovi in northern Borneo. This form of $A$. cerana is among the smallest of that species size range.

\section{MATERIALS AND METHODS}

Colonies of cavity-nesting bees in northern Borneo were sampled; worker bees were taken from 9 colonies of $A$. koschevnikovi and 4 colonies of $A$. cerana. Ten workers from each colony were dissected and 36 morphometric measurements were made. These measurements and their alphabetical designations given in Table I follow the system of morphometric analysis described by Ruttner et al. (1978) and Ruttner (1988). Numerical designations for wing venation angles are presented in Fig. 1 and Table I and are a combination of the angles studied by Ruttner et al. (1978) and Daly \& Balling (1978). For the most part, numbers represent lengths or widths of various structures and are reported in $\mathrm{mm}$. Interior angles of vein intersections in wing venation patterns are reported in degrees. Pigmentation characteristics of the second, third and fourth tergites are scored according to the procedures of Ruttner et al. (1978) and Ruttner (1988). Scores represent the proportion of comparatively light areas to the total area of the tergite. For $A$. koschevnikovi, the comparatively dark areas are rufus; for the sympatric $A$. cerana of Borneo, the comparatively dark areas are black. Figure $2 \mathrm{~A}$ shows characteristic patterns for all 3 tergites for bees of both species. Figure $2 B$ identifies the scutellum (Sc) and the surrounding metatergal $(R)$ and mesotergal (K) sclerites. Scores for the color intensity of Sc range from 0 to 9 , with 0 being completely black (A. cerana) or red (A. koschevnikovi). A scale ranging from 0 to 5 was used for $B$ and $K$; completely black ( $A$. cerana) or red ( $A$. koschevnikoVi) being equal to 0 , and completely yellow being equal to 5 .

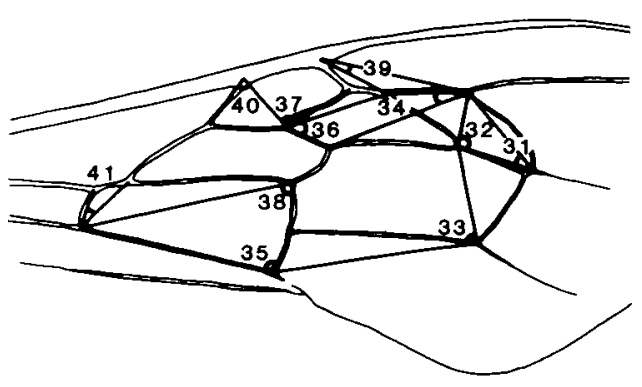

Fig. 1. Wing venation measured for $A$. koschevnikovi and $A$. cerana. The eleven angles are indicated on a representation of the wing of $A$. koschevnikovi and follow a unique numbering system combining the measures of Ruttner et al. (1978) and Daly and Balling (1978). 
A. koschevnikovl

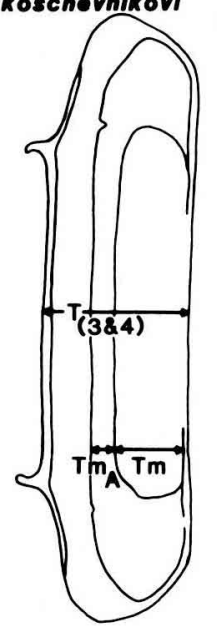

A. cerane

C

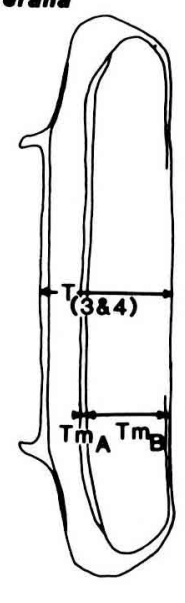

A. koschernikovi

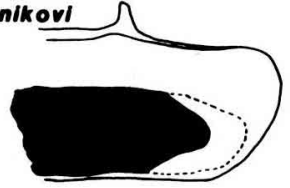

A

A. cerane
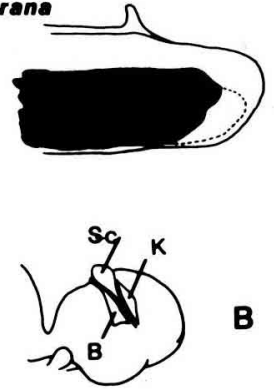

B

Fig. 2. A. Pigmentation on tergites 2,3 and 4 follow the scheme of Ruttner et al. (1978), although neither species follows the exact patterns indicated for $A$. mellifera. B. Coloration scale used for the scutellum (Sc) metatergum (B) and mesotergum (K) follows that of Ruttner et al. (1978) as does the illustration. C. Linear measurement of tergites from $A$. koschevnikovi and $A$. cerana. The measurement $T$ is made for tergites 3 and 4 . The measurements $T m_{A}$ and $T m_{B}$ are from tergite $4 . T m_{A}$ is a distance on that portion of the tergites which is lightest and $T \mathrm{~m}_{\mathrm{B}}$ is a distance on that portion of the tergite which is darkest.

After measurements were made on individual bees, colony averages for each characteristic were calculated. These averages were used to calculate means, variances and ranges for each measurement within each species. The colony averages were also used to calculate $t$-test evaluations of differences between the 2 species for each characteristic.

\section{RESULTS}

Apis koschevnikovi is larger than the sympatric $A$. cerana. Linear measurements of wings, legs and sclerites of $A$. koschevnikovi are consistently 10 to $15 \%$ larger than similar measurements of sympatric $A$. cerana. Of the linear measurements, 15 or
17 are larger for A. koschevnikovi (Table 1). The width of the sternum (St) $\left(W_{D}\right.$ in Ruttner, 1988) of the third sternite is larger for the $A$. cerana we measured. This may be a general characteristic of smaller bees since Africanized $A$. mellifera which are smaller than European $A$. mellifera, also have a wider sternum as part of the third sternite.

The overall longitudinal length of $A$. koschevnikovi tergites is larger; however, the tomentum measures are such that a larger proportion of the tergites are covered by the darker tomentum $\left(\mathrm{Tm}_{\beta}\right)$ in $A$. cerana. In A. koschevnikovi the proportion of the tergites covered by $\mathrm{Tm}_{\beta}$ is much smaller (Fig. 2C). This trend is apparent in the tomentum patterns of the second, third and fourth tergites. These patterns contribute 


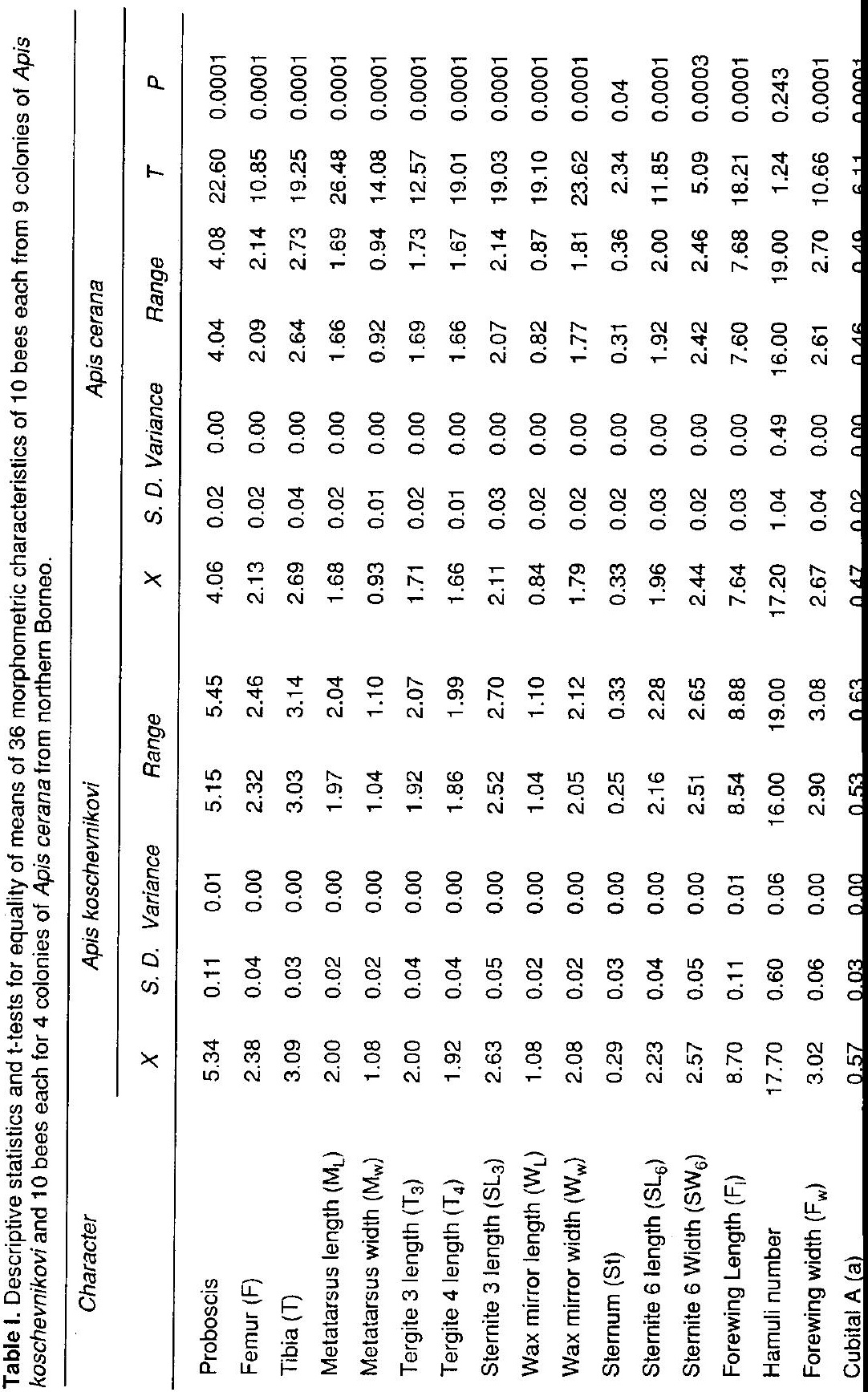




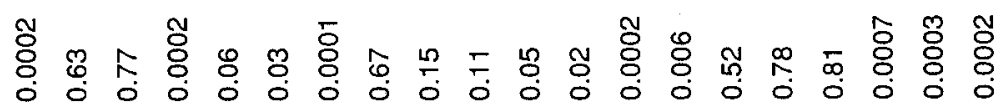

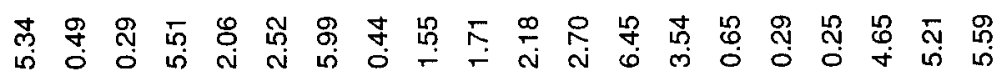

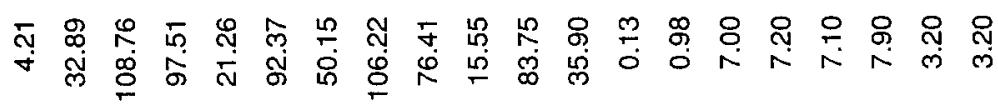

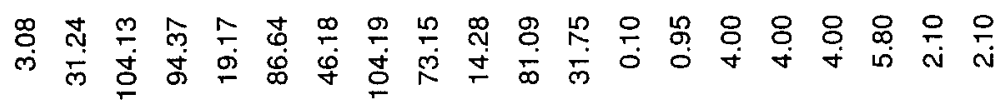

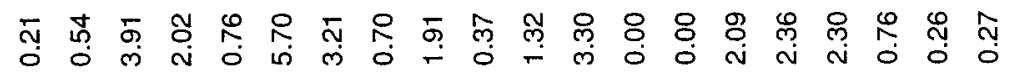

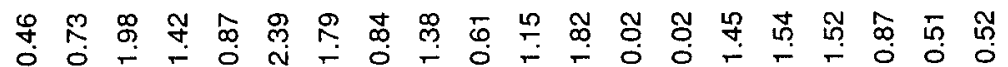

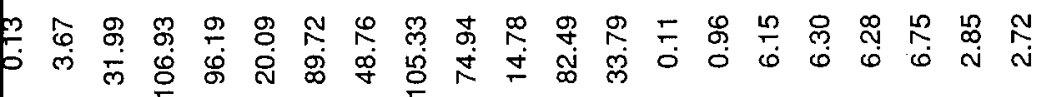

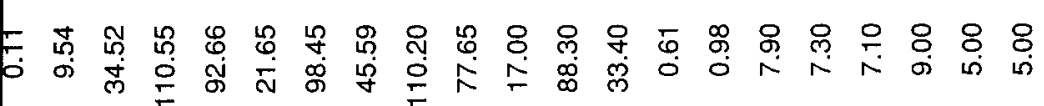

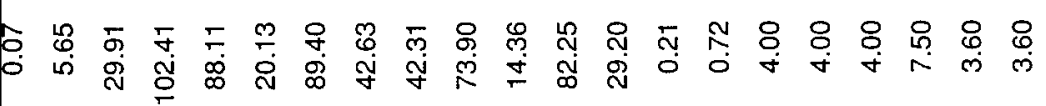

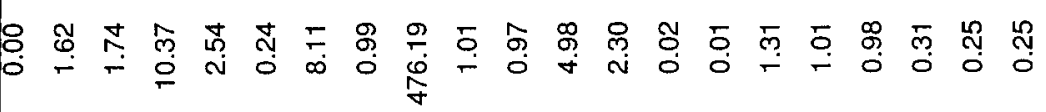

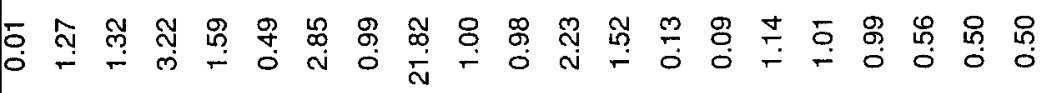

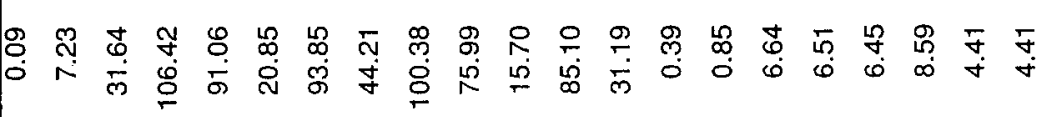

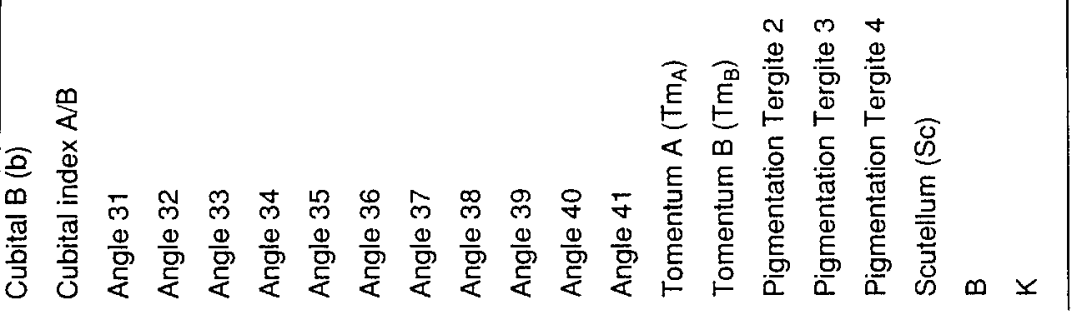


to the general impression of $A$. koschevnikovi of being a lightly colored rufus bee, while the sympatric $A$. cerana is intensely black.

The wing vein section, identified as cubital $b$, is generally longer in $A$. cerana. This, in combination with the opposite in measurements of the cubital a vein, leads to a much larger cubital index for $A$. koschevnikovi. This is the most exceptional of several differences in wing variation. Of the 11 venation angles, 5 of them are significantly different between the species (Table I; $P \leq 0.05$ ).

\section{DISCUSSION}

Overall, $A$. koschevnikovi has a very different morphology from the sympatric $A$. cerana and from all other well-described forms of honeybees. None of the differences presented here suggest additional species-specific characteristics for $A$. koschevnikovi. However, the entire constellation of measurements provides a picture of a remarkably different honeybee, unique in its morphological organization.

Much remains to be learnt about $A$. koschevnikovi. Its range and population size are among the most important of issues that require study. Answers to these questions will provide a better appreciation of the evolutionary origins of this species.

Résumé - Comparaison morphologique des abeilles de Bornéo qui nidifient dans les cavités : Apis koschevnikovi (Buttel-Reepen, 1906) et Apis cerana (Fabricius, 1793). Une description morphologique complète, utilisant les caractères habituels de la taxonomie de l'abeille, est donnée pour Apis koschevnikovi (Buttel-Reepen, 1906) et $A$. cerana (Fabricius, 1793) du nord-est de Bornéo. Dans l'ensemble $A$. koschevnikovi est plus grande que l'espèce $A$. cerana qui lui est sympatrique. Les mesures linéaires des ailes, des pattes et des sclérites d'A. koschevnikovi sont supérieures de 10 à $15 \%$ à celles de $A$. cerana (Tableau I).

Les diamètres longitudinaux des sclérites sont en général plus grands chez $A$. koschevnikovi. Les bandes tomenteuses laissent libre chez $A$. cerana une bande plus large du tergite sombre. La pilosité donne l'impression générale d'être plus claire et plus rougeâtre chez $A$. koschevnikovi, plus intensément noire chez l'abeille sympatrique $A$. cerana.

Pour la vénation alaire la différence la plus marquante est l'index cubital beaucoup plus élevé chez $A$. koschevnikovi $(7,23)$ que chez $A$. cerana $(3,67)$ (Tableau 1). Sur les 11 angles intérieurs des intersections des veines, 5 sont significativement différents entre les deux espèces (Tableau I). L'ensemble des caractères donne d'A. koschevnikovi l'image d'une abeille nettement différente, unique dans sa structure morphologique.

Zusammenfassung - Ein morphologischer Vergleich der höhlebrütenden Honigbienen von Borneo : Apis koschevnikovi (Buttel-Reepen, 1906) und Apis cerana (Fabricius, 1793). Unter Benutzung der in der Taxonomie der Honigbienen üblichen Merkmale wird eine vollständige morphologische Beschreibung von Apis koschevnikovi (Buttel-Reepen, 1906) und von $A$. cerana von Nordborneo vorgelegt. Im ganzen ist $A$. koschevnikovi größer als die mit ihr sympatisch lebende A. cerana. Die linearen Maße von Flügeln, Beinen und Skleriten sind bei $A$. koschev- 
nikovi durchgehend um 10-15\% größer als bei A. cerana (Tab. I).

Die Längsdurchmesser der Sklerite sind bei $A$. koschevnikovi allgemein größer. Die Filzbinden lassen bei $A$. cerana einen breiteren Streifen der dunklen Rückenschuppen frei. Die Tomentbehaarung führt zu dem allgemeinen Eindruck von $A$. koschevnikovi als einer hellen, rötlichen Biene, und der sympatischen $A$. cerana als einer intensiv schwarzen.

Der deutlichste Unterschied bei der Flügeläderung ist der viel größere Cubitalindex von $A$. koschevnikovi $(7,23)$ gegenüber $A$. cerana mit einem $\mathrm{Cl}$ von 3,67 (Tab. I). Von 11 Winkeln zwischen den Flügeladern waren fünf zwischen den beiden Arten signifikant verschieden (Tab. 1). Die ganze Zusammensetzug der Merkmale ergibt für $A$. koschevnikovi das Bild einer deutlich unterschiedlichen Honigbiene, einzigartig in ihrem morphologischen Aufbau.

\section{ACKNOWLEDGEMENT}

This study was made in cooperation with Louisiana Agricultural Experiment Station.

\section{REFERENCES}

Buttel-Reepen H. (1906) Beiträge zur Systematik, Biologie, sowie zur geschichtlichen und geographischen Verbreitung der Honigbiene (Apis mellifera L.), inner Varietäten und der übrigen Apis-Arten. Mitt. Zool. Mus. Berlin. 3, 117-201

Daly H.V. \& Balling S.V. (1978) Identification of Africanized honey bees in the Western Hemisphere by discriminant analysis. J. Kansas Entomol. Soc. 51, 957-969

Koeniger N., Koeniger G., Tingek S., Mardan M. \& Rinderer T.E. (1988) Reproductive isolation by different time of drone flight between Apis cerana (Fabricius 1793) and Apis koschevnikovi (Buttel-Reepen 1906). Apidologie 19, 103-106

Maa T. (1953) An inquiry into the systematics of the tribus Apidini or honeybees (Hym.) Treubia 21, 525-640

Mathew S. \& Mathew K. (1988) The "red" bees of Sabah. Newsl. Beekeepers Tropical Subtropical Countries. 12, Int. Bee Res. Assoc. p. 10

Ruttner F. (1988) Biogeography and Taxonomy of Honeybees. Springer Verlag, Heidelberg

Ruttner F., Kauhausen D., Koeniger G. (1989) Position of the red bee, Apis koschevnikovi (Buttel-Reepen 1906) within the genus Apis, Apidologie 20, 395-404

Ruttner F., Tassencourt L. \& Louveaux J. (1978) Biometrical-statistical analysis of the geographic variability of Apis mellifera L. Apidologie 9, 363381

Tingek S., Mardan M., Rinderer T.E., Koeniger N. \& Koeniger G. (1988) The Rediscovery of Apis vechti Maa 1953 : the Saban honeybee. Apidologie 19, 97-102 